\title{
The Communication Patterns of Single Parent Families in Forming Children's Morals in Medan City
}

\author{
Suheri $^{1}$, Syukur Kholil ${ }^{2}$, Lahmuddin Lubis ${ }^{2}$ \\ ${ }^{I}$ Ph.D Student in Islamic University Of North Sumatera (UINSU), Medan, Indonesia \\ ${ }^{2}$ Lecturer in Islamic University Of North Sumatera (UINSU), Medan, Indonesia
}

\begin{abstract}
This study aims to analyze the communication patterns of single parents in forming children's morals in Medan city, to analyze the application of single parent communication patterns in forming children's morals in Medan city and to analyze the moral development of children who have single parents in Medan city. This research is a descriptive qualitative approach. This method describes the state of the subject or object of research at this time based on facts that are visible or as they are. The results of the research conducted show the Communication Pattern of Parents in Forming Children's Morals in the Medan City, namely: a. Authotarian pattern, this relationship pattern of parents is low in forming children's morals in Medan city, but the control is high, likes to punish physically, behave in a command, being stiff (hard), tends to be emotional and rejects the opinions of children. b. Permissive pattern, in this pattern the attitude of parents is high in shaping children's morals in Medan city, but the control is low, giving freedom to children, $c$. The authoritative pattern, in this pattern parents and their control are high in shaping children's morals in Medan city, being responsive to the needs of children, accepting children's opinions.
\end{abstract}

Keywords : communication patterns; single parents; child morals in Medan city

\section{Introducation}

A child is the biggest gift which is given by Allah to married couple. A child is the most valuable asset for married couple. But on the other hand the child is the trust that God gives to the parents and as a test for both. ${ }^{1}$

Every parent would want the child to be a person with good personality, healthy mental attitude and commendable character. Parents are the first personal formers in a child's life, and will be a good example for the children. As stated by Zakiyah Daradjat, that parental personality, attitudes and ways of life are elements of education that will indirectly enter the personality of a growing child. ${ }^{2}$

The morality of the parents is very emphasized by the teachings of Islam and even the sins of children to parents, including major sins, which torture is not only obtained in the hereafter, but also in life in the world. The principles in carrying out easy morals towards parents are obedient, that is obeying their orders, unless the command is contrary to Allah's command, which is to do them throughout his life. By being gentle in words and actions, humbling themselves in front of them, thanking them, helping them in various ways and opportunities, caring for them when they are sick and shedding them when they die and praying for them. ${ }^{3}$

The number of children who have been left behind by parents either dead or divorced in the Medan city has made researchers interested in studying more deeply the morals of children who have single parents. The development of behavior and morality of children in Medan city is inseparable from the pattern of parental communication that is built for the moral formation

\footnotetext{
${ }^{1}$ Mushthafa al-`Adawi, Ensiklopedi Pendidikan Anak, (Bogor: Pustaka Al-Inabah, 2006)

2 Zakiyah Daradjat, Ilmu Jiwa Agama, (Jakarta: Bulan Bintang, 2005), p. 46

${ }^{3}$ Ibid, p. 27.
} 
of the child. The researcher saw the development of children's morals in the Medan city also influenced by the environment of residence and the child's social environment.

The number of children who have poor morals in Medan city is also influenced by parental control in forming the morals of their children. Moral formation for children is formed in a family, so researchers want to see how the communication pattern of single parents in forming morals of their children in Medan city.

\subsection{Communication Pattern}

\section{Review of Literature}

The communication pattern is a simple description of the communication process that shows the connection between one component of communication with other components. Communication pattern is defined as the form or pattern of relations between two or more people in the process of sending, and receiving the right way so that the message in question can be understood.

From the above understanding, a communication pattern is a form or pattern of relations between two or more people in the process of linking two components, namely a picture or plan that becomes steps in an activity with components that are an important part of the relationship between organizations or humans. There are three communication patterns in the relationship between parents and children, namely:

a. Authotarian (Tending to be hostile)

In this relationship pattern the acceptance attitude of parents is low, but the control is high, likes to punish physically, behave in command (requires / instructs children to do things without compromise), sticks hard (hard), tends to be emotional and resist. Whereas on the part of the child, the child is easily offended, timid, moody and feels unhappy, easily affected, stressed, they has no clear future direction.

For example, authoritarian parents might say, "Do it asnI say. There is no discussion!" Children from authoritarian parents often behave in ways that are less socially competent. They tend to worry about social comparison, fail to start activities and have poor communication.

b. Permissive (Tends to behave freely)

In this case the acceptance attitude of parents is high, but the control is low, giving freedom to the child to express their encouragement or desire. While children are impulsive and aggressive, lack self-confidence, dominate, unclear direction of life and low achievement.

Not all parents can understand the choices of their teenagers. For parents who can understand the wishes of their children who have reached adolescence, then usually parents from the beginning have provided good education, guidance and direction so that their children are careful in their association with their peers. But it turns out that many parents don't understand.

c. Authoritative (Tends to avoid anxiety and chaos)

In this case the acceptance of parents and controls is high, being responsive to the needs of children, encouraging children to express opinions or questions, giving an explanation of the effects of good and bad deeds. Whereas children are friendly, have self-confidence, are able to control themselves (self control) to be polite, cooperate, have high curiosity, have a clear purpose and direction of life and are achievement oriented.

Authoritative parents might hug their children in a fun way and say, "You know you shouldn't do that. Let's talk about how you can handle the situation differently later on." 
Children who have authoritative parents often behave in a socially competent manner. They tend to be confident, can delay desires, be familiar with their peers, and show high self-esteem.

\subsection{Single Parent}

a. Single Parent Definition

Single parent families are families whose parents only consist of mother or father who are responsible for managing after divorce, death or birth of children out of wedlock. Families have a very important role in efforts to develop the child's personal. The care of parents who are full of love and education about the values of life, both religious and socio-cultural given is a conducive factor for preparing children to be healthy individuals and members of society. ${ }^{4}$

The definition of single parent in general is single parents. Single parents care for and raise their own children without the help of a partner, both the husband and wife. Single parents have a very big obligation in managing their families. Single parent families have the most complicated problems compared to family who has a father or mother. Single parent can occur due to death or divorce.

Based on the above opinion, a single parent or single parent is a father or a mother who carries her own duties as a family head and also in raising and educating children without assistance from their partners.

b. Single Parent's Responsibilities

The integrity of parents (father and mother) in a family is really needed in helping children to have and develop the basics of self discipline. The family is said to be intact, if in addition to its complete members, it is also felt complete by its members, especially their children. ${ }^{5}$

The responsibilities and tensions faced by single parents are certainly heavier than those faced by parents who are intact or complete when raising children. Single parents have little time and often have fewer financial resources. Some parents are single, such as widows and widowers or foster parents, experience special tension. Older widows or widowers experience great sadness and life changes that can limit their ability to deal with a child's attitude. ${ }^{6}$

The role and responsibility of mother and father as a single parent will increase, they must earn their own living, make important decisions themself, and many tasks or responsibilities must be carried out as single parents. Major changes that must be carried out by the mother as a mother as well as father, on the contrary a father must carry out his role as father as well as mother. Single parent even though without the help of their spouse continue to run well as the backbone of the family and also as role models for their children.

Based on the explanation above, the responsibility of a single parent must also work to make a living for their family and must also educate and play a dual role as a father and mother for their children. Thus, there will be a different parenting pattern that has been described above.

c. Factors Causing Single Parents

\footnotetext{
${ }^{4}$ Syamsu, Yusuf, Psikologi Perkembangan Anak dan Remaja (Bandung: Remaja Rosdakarya, 2010), p. 37.

${ }^{5}$ Moh. Shochib, Pola Asuh Orang Tua Untuk Membantu Anak Mengembangkan DisiplinDiri, (Jakarta: Rineka Cipta, 2000), p. 18.

6 22C. Drew, Edwars, Ketika Anak Sulit Diatur: Panduan Bagi Para Orang Tua Untuk Mengubah Masalah Perilaku Anak, (Bandung: Kaifa, 2006), p. 52.
} 
Families consisting of father, mother and child are called intact families. The phenomenon that we encounter now is that more and more families are not intact such as without a father or without a mother. Life like this is caused by several factors, such as divorce, partner death, extramarital pregnancy or wish to not marry and decide to adopt a child.

Single parent is a woman or man who becomes a parent who captures as both father and mother or vice versa in raising and educating children, and regulating family life because of changes in family structure either because the spouse is left behind due to divorce or death.

Single parent can be caused by several factors such as divorce because of incompatibility or due to economic factors, accidental death or continuous illness, because one partner is a drug addict and an inmate so that his responsibilities in the family cannot be expected, an extramarital pregnancy, for a woman or men who don't want to marry then adopt someone else's child.

\subsection{Morals according to the Islamic Concept}

a. Understanding Morals

The word moral is plural of the word khilqun or khuluqun which means the same as the meaning of morality. ${ }^{7}$

Morals in the Qur'an as the word of Allah suratAl-Qalam verse 4.

Meaning: and you are certainly on the most exalted standard of moraĺ excellence. ${ }^{8}$

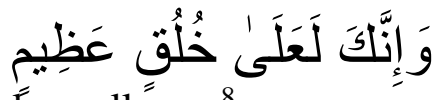

According to the general dictionary Indonesian language morals are character, character and tabi at. ${ }^{9}$ Morals come from the word "akhlaq" which is a jama` from "khulqudari Arabic which means temperament, kindness, wisdom and adab. The morals are divided into noble morals (Al-Akhlaqul Mahmudah) and bad morals (Al-Akhlaqul Mazmumah). ${ }^{10}$

Moral according to language means behavior, temperament, or tabi'at. While according to the term is knowledge that explains both good and bad, regulates human interaction and determines the ultimate goal of the business and its work. Morals are inherently inherent in a person, united with behavior or actions. inherent behavior is bad, so called bad morality (mazmumah), on the contrary, if the behavior is good then it is called the noble character (akhlakul mahmudah). ${ }^{11}$

The word "morals" comes from Arabic, namely the form of jama'dari the word "khulukun" which means temperament, behavior, or tabi 'at. In this case Al-Qurtubi added that the word "khuluq" also means adab or ethics that control someone in behaving and act. ${ }^{12}$

\footnotetext{
${ }^{7}$ Abuddin Nata, Akhlak Tasawuf, (Jakarta: Rajawali Pers, 2011), p. 2.

${ }^{8}$ Ministry of Religious Republik Indonesia, Mushaf Al-Qur'an dan Terjemahannya, (Jakarta: Pustaka AlKausar, 2009), p. 564.

${ }^{9}$ Ministry of Religious Republik Indonesia, Mushaf Al-Qur`an dan Terjemahannya, (Jakarta: Pustaka AlKausar, 2009), p. 564., Kamus Umum Bahasa Indonesia, (Jakarta: Balai Pustaka, 2007), p. 18

${ }^{10}$ Damanhuri Basyir, Strategi Pembentukan Manusia Berkarakter” Refleksi Konsep InsanKamil dalam Tasawuf' (Banda Aceh: Lembaga naskah Aceh dan Arraniry Press, 2013), p. 3.

${ }^{11}$ Damanhuri Basyir, Strategi Pembentukan Manusia Berkarakter" Refleksi Konsep InsanKamil dalam Tasawuf", p. 23.

${ }^{12}$ Husnizar, Konsep Subjek Didik dalam Pendidikan Islam “ Suatu Telaah Perkembangan Spiritual danIntelektual Subjek Didik, p. 199
} 


\section{b. Moral division}

The moral scholars state that good morals are the nature of the Nabi and Siddiq people, while bad morals are satanic and despicable people. So basically, morality becomes two kinds, including:

- Good or commendable morality (Al-Akhlaaqul Mahmudah), which is good deeds to Allah, fellow human beings and other creatures.

- Bad or despicable morals (Al-Akhlaaqul Madzmumah), namely bad actions towards Allah, fellow humans and other creatures. ${ }^{13}$

c. Factors Affecting Moral Formation

According to Abuddin, the factors that influence moral formation in particular and education in general, there are three very popular schools, namely: ${ }^{14}$

- Nativism flow

According to the flow of nativism that the most influential factors towards the formation of a person is the innate factor in the form that can be in the form of tendencies, talents, reason, etc. If someone has a disposition or tendency to the good, then the person is good, so sure of the inner potential that exists in humans and lacks respect or lack of account for the role of coaching and education.

- Flow of Empiricism

According to the empiricism school, the most influential factor towards one's selfformation is an external factor, namely the social environment, including the formation and education given to the child is good, well the child. This is the case if the opposite. This flow seems more like a role for the world of education and teaching.

- Convergence Flow

Convergence flow argues that moral formation is influenced by internal factors, namely the nature of the child, and external factors, specifically education and coaching, or through interaction in social environments. The image and the tendency toward good that exists in human beings is intensively through various methods.

\subsection{Fundamentals of Communication in the Family}

Communication is a relationship of contact between humans, both individuals and groups. In daily life it is realized or not communication is part of human life. Every person who lives in the community, from waking up to sleeping again, is naturally involved in communication. Even since humans are born already communicating with their environment. The first movement and crying at the time of birth is a sign of communication. The occurrence of communication is a consequence of social relations. The community consists of at least two people who are interconnected with each other because they are related to social interaction. The occurrence of interactions is due to intercommunication. ${ }^{15}$

In communication, anything that individuals or groups want to convey to others is with a variety of purposes and objectives. Therefore, communication carried out by individuals or groups is not always the same, but with different levels of depth. The level of depth of

\footnotetext{
${ }^{13}$ Mahyuddin, Kuliah Akhlak Tasawuf..., p. 9.

${ }^{14}$ Abuddin Nata, Akhlak Tasawuf..., p. 166.

${ }^{15}$ Syaiful Bahri Djamarah, Pola Komunikasi Orang Tua dan Anak Dalam Keluarga, (Jakarta: Rineka Cipta, 2004) p. 9
} 
communication can be measured from what and who are discussed, thoughts or feelings, certain objects, other people or themselves. The more people want to talk to each other about feelings that are in themselves, certain objects or other people, the deeper the level of communication that occurs. Based on this level of depth John Powell distinguishes communication in five levels, namely the level of trite, talking about other people, expressing ideas and opinions, expressing the contents of the heart or feeling and peak relationships.

The toughest and most difficult battle of feelings made by someone is to express the contents of the heart to others. Let alone to ordinary friends, to parents is difficult to do if someone does not open themselves to believe in others. Usually people who can believe are people who are close or well-known and believed to have good personalities with attitudes and behaviors that are symbolized by honesty, openness and understanding. Therefore, the prerequisite for expressing heart content is the opening of trust in others. But no less important is the person who is trusted can keep the secrets of others.

\section{Discussion}

From the searches that researchers conducted on the communication patterns of single parents in forming children's morals in Medan city, researchers found three communication patterns, namely:

\subsection{Authotarian Pattern}

In this relationship pattern, the acceptance attitude of parents is low in forming children's morals in Medan city, but the control is high, likes to physically punish, behave (requires / instructs children to do things without compromise), is stiff (hard), tends to be emotional and behave reject. Whereas on the part of the child, the child is easily offended, timid, moody and feels unhappy, easily affected, stressed, has no clear future direction.

In raising children to be better, parents are also obliged to provide moral education to their children. Morals have a very important role for humans, he can deliver to good and honor both living in the world and the hereafter, it all depends on how it functions, if the words and behavior are used to say and talk about good and good behavior, it will bring and deliver people to goodness and salvation. But if words and behavior are used to talk about bad, evil and vile things, it will lead to accidents and destruction in the world and the hereafter.

Words are like a sword that if not used properly it will endanger ourselves. Every good word will bring goodness and every bad word will bring harm to oneself and others such as disputes, hatred, and conflict. ${ }^{16}$ Therefore, Islam reminds us to guard ourselves from bad words. God's Word in surah Al-Isra 'verse 53:

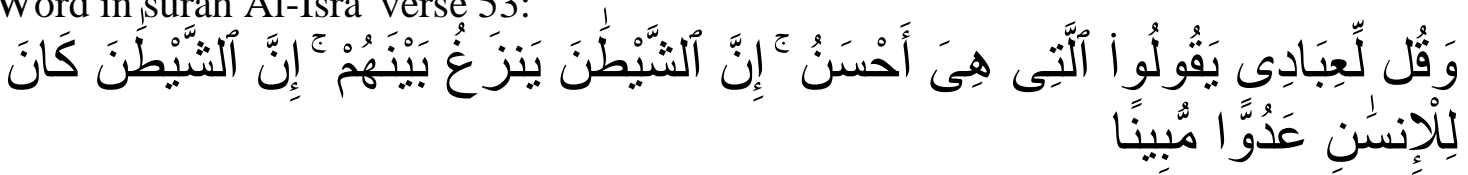

Meaning: And tell My servants to say that which is best. Indeed, Satan induces [dissension] among them. Indeed Satan is ever, to mankind, a clear enemy. ${ }^{17}$

\footnotetext{
${ }^{16}$ Haryanto Al-Fandi, Etika Bermuamalah, (Jakarta: Amzah, 2011), p.48

${ }^{17}$ Departemen Agama RI, Alquran dan Terjemahannya, (Jakarta: Serajaya Santra, 1987), p. 287
} 


\subsection{Permissive Pattern}

In this pattern, parents' attitudes are high in forming children's morals, but the controls are low, giving children the freedom to express their encouragement or desires. While children are impulsive and aggressive, lack self-confidence, dominate, unclear direction of life and low achievement.

Communication patterns like this can cause children to be not in accordance with parental expectations, where children will be easily affected by an environment that is not good if parents do not play an active role in monitoring their children's relationships.

Families that present children to this world, in nature have the duty to educate the child. Since childhood, the child grows and develops in the family. In this case, of course the role of the father and mother is very decisive, instead they are the one who holds the responsibility of the whole family. They are the ones who determine where the family will be taken, what color must be given to the family, what content must be given to the family, and so on is totally determined by both of them. Children before being able to take responsibility for themselves, are still very dependent, still receive content, provisions, ways of acting on something, ways of thinking from their parents. ${ }^{18}$

\subsection{Authoritative Pattern}

In this pattern, parental acceptance and control is high in forming children's morals, being responsive to children's needs, encouraging children to express opinions or questions, giving explanations about the effects of good and bad deeds. Whereas children are friendly, have self-confidence, are able to control themselves (self control) to be polite, cooperate, have high curiosity, have a clear purpose and direction of life and are achievement oriented.

The interaction between parents and children is very visible in terms of fostering the child itself which includes giving advice, advice, orders, habituation or also in terms of giving punishment, threats and warnings. Examples of examples are techniques or ways that every parent (especially a mother who has a lot of children) every day shows directly good deeds and attitudes, so that the child can see those actions and attitudes directly. Thus the child imitates the attitudes and actions of his master. This process runs naturally because children have imitating qualities, especially the actions of the people they like.

Therefore parents must be aware that their interactions with their children are based on aspects of affection. If this is created, then parents (mothers) can easily establish good interactions with their children. In line with that, the mother will easily influence the child with examples that are always shown to the child. This concept must be created until the child becomes an adult.

Authoritative parents might hug their child in a pleasant way and say, "You know you shouldn't do that. Let's talk about how you can handle the situation differently later on." Children who have authoritative parents often behave in a socially competent manner. They tend to be confident, can delay desires, be familiar with their peers, and show high self-esteem.

Etymologically moral comes from Arabic akhlaqa, yukhliqu, ikhlaqan, and jama, khuluqun which means temperament (al-sajiyah), customs (al'adat), character, behavior or character (ath-thabi'ah), differences the good (al-maru'ah), and religion (ad-din). While the definition of morality in terminology can be seen from the opinion of the expert Ibn Maskawih

\footnotetext{
${ }^{18}$ Agus Sujanto, Psikologi Kepribadian, (Jakarta Bumi Aksara, 1980), p. 8-9
} 
akhlak jama' form of the word khuluq which gives the understanding of khuluq as a state of soul that drives it to do deeds deeds without thought and calculated beforehand. ${ }^{19}$

The verse that explains about morals is found in surah Al-Ahzab verse 21:

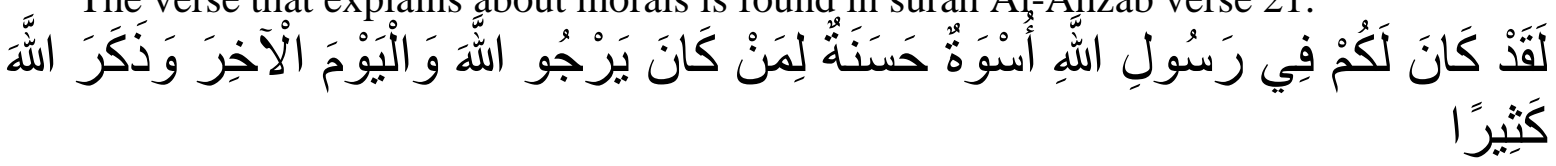

Meaning: Surely there was a good example for you in the Messenger of Allah, for all those who look forward to Allah and the Last Day and remember Allah much. ${ }^{20}$

The communication Patterns of Single Parent Families in Raising Children Morals

The application of communication patterns of single parent in forming children's morals uses interpersonal communication between parents and children, where each can choose a function both as a communicator and communicant that has a steady and clear relationship, meaning almost inevitably there is always a certain relationship between these two people.

Interpersonal relationships occur through unintentional events or intentional relationship choices. The relationship between parents and children is a relationship that is intertwined due to blood relations so that it can be categorized as an intentional relationship.

Trust, familiarity and power are important elements in interpersonal relationships. Trust is the level at which we feel safe sharing information with others. Familiarity is the level at which we can be ourselves in front of others and still be accepted by them. Power is the ability to influence others according to our direction, which is directing others to do what we want. Power as control and at least differentiated into two continuum, namely: rigid flexible and unstable. Rigidity refers to the lack of changing patterns of transactions while stability refers to the ability to predict a pattern.

\section{Conclusion}

Based on the descriptions that have been stated in the previous chapters, the analysis can be drawn as follows:

a. Authotarian pattern, this relationship pattern of parents is low in forming children's morality in Medan, but the control is high, likes to punish physically, behave in command (requires / does not do things without compromise), is stiff (hard), tends to be emotional and resist against the opinions of children. The impact of parents who have a strong attitude and striking against opinions, children easily caught up, become timid children, like moody, easily affected, like to fantasize, stress and in friendship are less friendly and less happy.

b. Permissive pattern, in this pattern the attitude of the tallest person in forming the morality of the city of Medan, but the control is low, giving freedom to children to express their encouragement or desires, parental attitudes like this are often used by children who are given freedom to act and socialize, while children behave impulsive and aggressive, lacking confidence in the work done, likes to dominate various opinions in the family and even likes to organize on the basis of his own interests, then the direction and goals are unclear, the direction of their life and achievement are low.

\footnotetext{
${ }^{19}$ Ibnu Maskawih, Tahzib al-Akhlak, translated Helmi Hidayat, (Jakarta: Mizan, 1999), p. 25

${ }^{20}$ Departemen Agama RI, Alquran dan Terjemahannya, (Jakarta: Serajaya Santra, 1987), p. 670
} 
c. The authoritative pattern, in this pattern parents and controls are high in forming children's morals in the city of Medan, being responsive to the needs of children, accepting children's opinions, encouraging children to express their opinions or questions, giving explanations about the effects of good and bad deeds on themselves and family. while the impact on the child becomes a child who is full of friendship, confidence, their actions are controlled, polite, like cooperation, high curiosity and purposeful aiming.

\section{References}

Al-Qur`annul Karim.

Abuddin Nata, Akhlak Tasawuf, Jakarta: Rajawali Pers, 2011.

Abu Ahmadi dan Munawar Sholeh, Psikologi Perkembangan, Jakarta: Rineka Cipta, 2005.

Alberta, Menjadi Orang Tau yang Sukses, Jakarta: Grasindo, 2000.

Ali Abdul Halim Mahmud, Akhlak Mulia, Jakarta: Gema Insani, 2004.

AN. Ubaedy, Cerdas Mengasuh Anak; Panduan Mengasuh Anak Selama dalam Periode 'Golden Age', Jakarta: KinzaBooks, 2009.

Anas Sudjono, Pengantar Statistik Pendidikan, Jakarta: Mutiara, 2007.

Burhan Bungin, Penelitian Kualitatif Edisi Kedua, Jakarta: Kencana Prenada Media group, 2011.

, Metodologi Penelitian Sosial Format-format Kuantitatif dan Kualitatif, Surabaya: Airlangga University Press, 2001.

C. Drew, Edwars, Ketika Anak Sulit Diatur: Panduan Bagi Para Orang Tua Untuk Mengubah Masalah Perilaku Anak, Bandung: Kaifa, 2006.

Damanhuri Basyir, Strategi Pembentukan Manusia Berkarakter" Refleksi Konsep Insan Kamil dalam Tasawuf" (Banda Aceh: Lembaga Naskah Aceh dan Arraniry Press, 2013. , Kawasan Studi Akhlak, Banda Aceh: Arraniry Press dan Lembaga Naskah Aceh, 2012.

Departemen Agama RI, Mushaf Al-Qur`an dan Terjemah, Jakarta: Pustaka Al- Kausar, 2009.

Departemen Pendidikan Nasional, Kamus Umum Bahasa Indonesia, Jakarta: Balai Pustaka, 2007.

, Kamus Besar Bahasa Indonesia, Jakarta: Balai Pustaka, 2005.

Diana Mutiah, Psikologi Bermain Anak Usia Dini, Jakarta: Kencana, 2012.

Djamarah, Syaiful Bahri, 2005, Guru Dan Anak Didik Dalam Intraksi Edukatif Suatu Pendekatan Teoritis Psikologis, Jakarta: PT. Rineka Cipta

G. Tembong Prasetya, Pola Pengasuhan Ideal, Jakarta: Elex Media Komputinto, 2003.

Husnizar, Konsep Subjek Didik dalam Pendidikan Islam "Suatu Telaah

Perkembangan Spiritual dan Intelektual Subjek Didik”, Banda Aceh: Ar- Raniry Press, 2007.

Iskandar Junaidi, Mencetak Anak Unggul, Yogyakarta: Andi Offset, 2011.

Janet Levine, Orang Tua Macam Apa Anda, Bandung: Kaifa, 2003.

Jhon W. Santrock, Adolescence (Perkembangan Remaja), Jakarta: Erlangga, 2003.

J.P Chaplin, Kamus Psikologi, Jakarta: Raja Grafindo Persada, 2006.

Kartono, Kartini, 1994. Kamus Psikologi. Bandung. Pustaka Sinar harapan

Komisi Perlindungan Anak Indonesia, pasal 1 ayat (5) undang-undang/ Nomor 23

Tahun Tentang Hak Asasi Manusia (HAM/ Perlindungan Anak, Menteng-Jakarta Pusat: 2008. Mahyuddin, Kuliah Akhlak Tasawuf, Jakarta: Kalam Mulia, 2001.

Mahmud Muhammad Aljauhari dan Muhammad Abdul Hakim Khayyal, Membangun Keluarga Qur'ani, Jakarta: Amzah, 2005. 
Moh. Shochib, Pola Asuh Orang Tua Untuk Membantu Anak Mengembangkan Disiplin Diri, Jakarta: PT Rineka Cipta, 2000),

Mussen, Perkembangan dan Kepribadian anak, Jakarta: Arcan, 1994.

Mushthafa al-`Adawi, Ensiklopedi Pendidikan Anak, Bogor: Pustaka Al-Inabah, 2006.

Mustofa, Akhlak Tasawuf, Bandung: Pustaka Setia, 2010.

Muhammad Rusli Amin, Rasulullah Sang Pendidik "Menyikapi Rahasia-rahasia

Pendidikan Karakter dari Sirah Nabi Muhammad SAW, Jakarta: AMP Press, 2013.

Nawawi H.Hadari, Metode Penelitian Bidang Sosial, Yokyakarta: Gajah Mada University Press, 2005.

Rifa Hidayah, Psikologi Pengasuhan Anak, Malang: UIN Malang Press, 2009.

Soejanto, 2001. Membentuk Pola Perilaku Manusia Pembangunan. IPB Press, Bogor.

Sugiyono, Metode Penelitian Kuantitatif, Kualitatif dan R\&D, Bandung: Alfabeta, 2010.

Syamsu, Yusuf, 2004. Psikologi Perkembangan Anak dan Remaja . Bandung: PT. Remaja Rosdakarya , Metode penelitian Kuantitatif Kualitatif dan R\&D, Bandung: Alfabeta, 2011.

Suharsimi Arikunto, Prosedur Penelitian, Jakarta: Rineka Cipta, 2006.

Syamsu Yusuf, Psikologi Perkembangan Anak dan Remaja Bandung: Remaja Rosdakarya, 2010.

Syaiful Bahri Djamarah, Pola Komunikasi Orang Tua dan Anak dalam Keluarga“

Sebuah Persepektif Pendidikan Islam Jakarta: Rineka Cipta, 2004.

William J. Godde, Sosiologi Keluarga, Jakarta: Bumi Aksara, 2002.

Wright, P.L. 1999. Motivation in organizations. In M. Smith (Ed), Analysing

Zakiyah Daradjat, Ilmu Jiwa Agama, Jakarta: Bulan Bintang, 2005. 